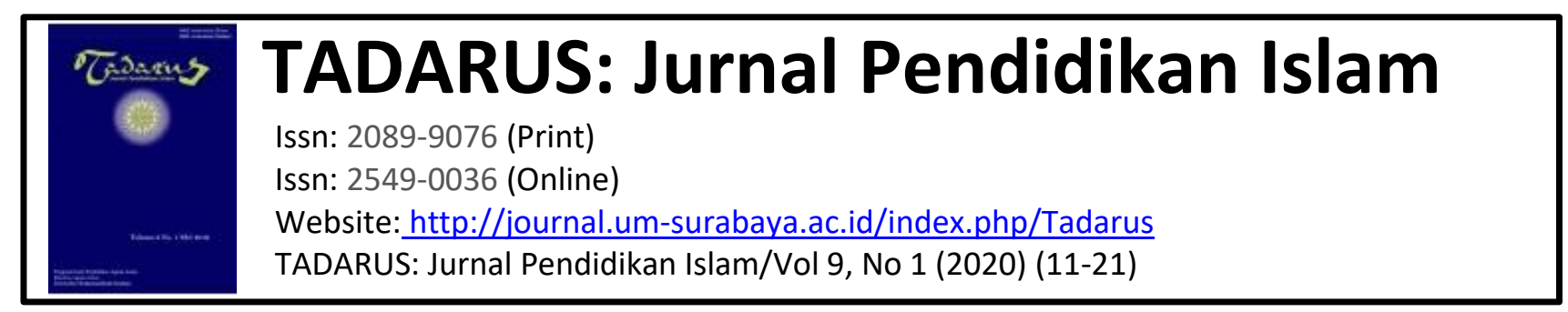

\title{
MUHAMMADIYAH DALAM PANDANGAN MITSUO NAKAMURA ANALISIS BUKU THE CRESCENT ARISES OVER THE BANYAN TREE A STUDY OF THE MUHAMMADIYAH MOVEMENT IN CENTRAL OF JAVANESE TOWN KARYA MITSUO NAKAMURA
}

\author{
${ }^{1}$ M. Arif Rohman Mauzen, ${ }^{2}$ Rusman \\ 1arifmauzen@gmail.com, ${ }^{2}$ rusman@ fai.um-surabaya.ac.id \\ Program Studi Pendidikan Agama Islam, Universitas Muhammadiyah Surabaya
}

\begin{abstract}
Abstrak
Mitsuo Nakamura dalam bukunya yang berjudul "The Crescent Arises over The Banyan Tree: A study of Muhammadiyah Movement in a Central Javanese Town", yang ditulis dalam versi bahasa Indonesia dengan judul "Bulan Sabit Muncul Dari Balik Pohon Beringin" studi pergerakan Muhammadiyah di Kotagede, Yogyakarta, mencoba menyajikan sejarah etnografi gerakan Muhammadiyah di Kotagede, Yogyakarta. Penulis mencoba mengkaji, bagaimana Muhammadiyah dalam pandangan Mitsuo Nakamura yang ditulis dalam buku tersebut. Hal ini sangat berguna, dari sisi sebagai kader Muhammadiyah dapat meningkatkan semangat dalam berorganisasi, sedangkan bagi masyarakat umum dapat menjadi media dalam mengenalkan organisasi Muhammadiyah.

Penelitian ini menggunakan pendekatan deskriptif kualitatif, penelitian deskriptif tidak bermaksud untuk menguji hipotesis, tetapi hanya menggambarkan tentang suatu organisasi Muhammadiyah. Penelitian ini menggunakan jenis penelitian kepustakaan, yaitu menganalisis rangkaian buku Mitsuo Nakamura tentang "Bulan Sabit Muncul Dari Balik Pohon Beringin" dengan metode pengumpulan data pustaka.

Dari hasil analisa penulis pandangan Mitsuo Nakamura terhadap Muhammadiyah yang antara lain adalah, (1) Muhammadiyah sebagai gerakan agama, yaitu gerakan pemurnian ajaran Islam dari budaya yang berasal dari luar Islam. (2) Muhammadiyah sebagai gerakan sosial, yaitu Muhammadiyah aktif dalam aktivitas sosial dalam bentuk amal usaha bidang kesehatan, dan bidang pendidikan. (3) Muhammadiyah sebagai gerakan ideologi, yaitu sikap Muhammadiyah tidak menolak budaya Jawa, tetapi menyaring intisari dari ajaran Islam dari budaya Jawa, sehingga muncullah yang disebut Islam Jawa.
\end{abstract}

Kata Kunci: Muhammadiyah, Agama, Sosial, Ideologi 


\section{Pendahuluan}

Studi terhadap organisasi Muhammadiyah pada umumnya melihat pada sisi Muhammadiyah sebagi gerakan agama, sosial dan ideologinya, hal itu memang penting dan merupakan sebuah keniscayaan. Tetapi ada hal lain yang tidak kalah penting adalah studi Muhammadiyah tentang program dan aktivitas yang bersifat praksis pada amal usaha yang telah dilakukannya. Hal ini berkaitan dengan peran Muhammadiyah dalam memenuhi hajat hidup masyarakat. Studi pada sisi Muhammadiyah sebagai gerakan agama diarahkan kepada upaya purifikasi dan studi pada sisi Muhammadiyah sebagai gerakan sosial diarahkan kepada kreasi, inovasi dan dinamisasi, sedangkan Muhammadiyah sebagai gerakan ideologi adalah diarahkan pada sikap toleransi kepada kebudayaan dan tradisi serta terhadap agama lain. Ideologi Muhammadiyah tentang Islam murni hanya berlaku bagi anggota Muhammadiyah dan tidak berlaku bagi yang lain.

Mitsuo Nakamura dalam bukunya yang berjudul "The Crescent Arises over The Banyan Tree: A study of Muhammadiyah Movement in a Central Javanese Town", yang ditulis dalam versi bahasa Indonesia dengan judul "Bulan Sabit Muncul Dari Balik Pohon Beringin" studi pergerakan Muhammadiyah di Kotagede, Yogyakarta, dalam buku ini Mitsuo Nakamura mencoba menyajikan sejarah etnografi gerakan Muhammadiyah di Kotagede, Yogyakarta. Disini penulis mencoba mengkaji, bagaimana Muhammadiyah dalam pandangan Mitsuo Nakamura yang ditulis dalam buku tersebut. Hal ini sangat berguna, dari sisi sebagai kader Muhammadiyah dapat meningkatkan semangat dalam berorganisasi, sedangkan bagi masyarakat umum hal ini dapat menjadi media dalam mengenalkan organisasi Muhammadiyah.

\section{Metodologi Penelitian}

Penelitian ini menggunakan pendekatan deskriptif kualitatif, penelitian deskriptif tidak bermaksud untuk menguji hipotesis, tetapi hanya menggambarkan tentang suatu variabel atau keadaan. ${ }^{1}$ senada dengan pernyataan yang dikemukakan oleh Winarno Surahman mengatakan bahwa metode penyelidikan deskriptif merupakan istilah umum yang mencakup berbagai tehnik deskriptif. Diantaranya adalah penyelidikan yang menganalisa, menuturkan dan mengklasifikasi. ${ }^{2}$

\footnotetext{
${ }^{1}$ Suharsimi Arikunto, Manajemen Penelitian, cet. Ke-3, (Jakarta: PT. Rieneka Cipta 1995), 310.

${ }^{2}$ Winarno Surahmad, Dasar Dan Tehnik Research Pengantar Metodologi Ilmiah, (Bandung:
} 
Penelitian ini menggunakan jenis penelitian kepustakaan (library research), yaitu rangkaian kegiatan yang berkenaan dengan metode pengumpulan data pustaka. ${ }^{3}$

Penelitian ini bertujuan untuk mengetahui pandangan Mitsuo Nakamura tentang Muhammadiyah dalam buku: "The Crescent Arises over The Banyan Tree" A Study of The Muhammadiyah Movement in Central of Javanese Town yang diterjemahkan ke dalam bahasa Indonesia oleh Yusron Asrofie dari Fakultas Ushuludin, Institut Agama Islam Negeri (IAIN) Sunan Kalijaga, Semarang. Sumber Data

Sumber data primer pada penelitian ini mengambil dari buku "The Crescent Arises over The Banyan Tree: A Study of The Muhammadiyah Movement in Central of Javanese Town" karena ini adalah penelitian kepustakaan atau Library Research karya Mitsuo Nakamura. Sumber data sekunder pada penelitian ini mengambil dari buku Muhammadiyah Jawa oleh Ahmad Najib Burhani, KH.Ahmad Dahlan : Biografi Singkat 1869-1923, Adi Nugroho, Muhammadiyah Gerakan Praksis Sosial Keagamaan Dengan semangat Altruisme dan Filantropisme, Mahsun, Muhammadiyah Sebagai Gerakan Tajrid dan Tajdid, Mahsun., Merambah Jalan Baru Islam Bahtiar Effendi dan Fahry Ali., Tarekat, Tasawuf, Tahlilan, dan Maulidan Hartono Ahmad Jaiz., Kyai Haji Ahmad Dahlan, Pemikiran dan kepemimpinannya, M.Yusron Asrofie

Teknik pengumpulan menggunakan metode dokumentasi. Suharsimi Arikunto berpendapat bahwa metode dokumentasi adalah mencari data mengenai hal-hal atau variabel yang berupa catatan, transkrip buku, surat kabar, majalah, prasasti, metode cepat, legenda dan lain sebaginya. ${ }^{4}$ Pada penelitian ini, metode induktif digunakan dalam menganalisa data yang diperoleh yakni data kualitatif, data yang tidak berbentuk angka walaupun ada kemungkinan adanya data kualitatif yang berbentuk angka yang kemudian dideskriptifkan secara verbal.

\section{Hasil dan Analisis Penelitian}

1. Hasil Penelitian

Mitsuo Nakamura dalam penelitiannya tentang Muhammadiyah di Kotagede menggunakan pendekatan sejarah serta etnografi, yaitu dengan mencari data sejarah

\footnotetext{
Tarsito), 131.

${ }^{3}$ Mahmud, metode penelitian pendidikan, (Bandung: pustaka setia, 2011),31.

4 Suharsimi Arikunto, Prosedur penelitian,Suatu pendekatan Praktik, (Jakarta: PT.Rineka Cipta, 2006), 234 .
} 
sebelumnya tentang objek penelitian, dalam hal ini Muhammadiyah. Data tentang Muhammadiyah diperoleh antara lain dari dua artikel yang semula diterbitkan pada tahun 1926 oleh van Mook, seorang pejabat pengawas bidang pertanian di Yogyakarta. ${ }^{5}$ Untuk mendukung dari data penelitiannya tentang Muhammadiyah sebagai gerakan agama, Mitsuo Nakamura mengamati perilaku dari pimpinan organisasi Muhammadiyah untuk dijadikan sebagai teks hidup. Hasil pengamatannya menunjukkan suatu hasil yang memperkuat penelitiannya, salah satunya adalah pengamatan kepada salah satu pimpinan Muhammadiyah di Kotagede yaitu Kyai Haji Mashudi, beliau dipilih karena Mitsuo Nakamura berpendapat bahwa di dalam riwayat hidup para pemimpin merupakan peralihan kepada orientasi agama dan sosisal yang baru secara jelas terwujud. Sebagai contoh ketika masyarakat di Kotagede berkeyakinan bahwa untuk membangun rumah harus menghadap ke arah selatan untuk menghormati Nyai Loro kidul, maka Kyai Haji Mashudi dalam penolakannya terhadap keyakinan itu dengan menggunakan dasar logika yang kuat, sehingga masyarakat dapat menerima alasan itu dengan baik, saat ditanya oleh penduduk setempat beliau mengatakan bahwa alasan membangun rumah tidak mengahadap ke selatan karena untuk mendapatkan ruang parkir bagi para tamunya dalam rangka peretemuan keagamaan di rumahnya.

Dari riwayat tersebut menunjukkan bahwa Muhammadiyah sebagai gerakan agama bergerak dalam rangka pemurnian ajaran agama Islam dari campuran keyakinan yang bukan berasal dari Islam, tapi tetap dengan cara yang santun dan tidak merendahkan. Dalam bab kesimpulan dari hasil penelitian dalam bidang antropologi Mitsuo Nakamura di Kotagede berpendapat bahwa Islam yang benar (ortodoks) dalam bentuk gerakan reformis, Muhammadiyah muncul dari kalangan Jawa tradisional, sebagai pejelmaan dari dalam, bukan sebagai impor ideologi baru, yang sudah sempurna di lain tempat, dan bahwa Islam ortodoks versi kaum reformis merupakan ideologi agama yang begitu memikat serta telah, sedang dan akan membawa perubahan-perubahan besar di dalam aspek sosial, kultural, ekonomi dan politik daripada kehidupan Jawa.

Muhammadiyah sebagai gerakan sosial menurut Mitsuo Nakamura adalah semua aktivitas sosial dan amal usaha yang dilakukan oleh Organisasi Muhammadiyah di Kotagede. Masyarakat Kotagede terutama anggota

\footnotetext{
${ }^{5}$ Mitsuo Nakamura,. The Crescent Arises Over The Banyan Tree: A Study of The Muhammadiyah Movement in Central of Javanese Town. (Yogyakarta: Gajah Mada University Press,1983),10.
} 
Muhammadiyah sangat bersemangat dalam kegiatan-kegiatan amal usaha bidang pendidikan dan kesejahteraan sosisal, sumbangan berupa wakaf tanah untuk lembaga agama dan sosial terutama didorong oleh tindakan yang bermanfaat sebagai pengabdian kepada Tuhan. Kegiatan sosial seperti inilah yang paling menonjol pada pergerakan Muhammadiyah di Kotagede. Pada akhir tahun 1920-an Muhammadiyah mendirikan HIS (sekolah dasar enam tahun dengan penegantar bahasa Belanda), kemudian mendirikan sekolah putri yang mengkhususkan dalam masalah rumah tangga, menjahit dan mengasuh anak. Mitsuo Nakamura mengakui bahwa sekolah Muhammadiyah mengalahkan sekolah Negeri pada saat itu selama masa sebelum perang, bahkan keluarga priyayi memasukkan anak-anak mereka ke dalam sekolah Muhammadiyah. Salah satu tokoh yang terkenal di Kotagede adalah Kyai Amir adalah salah satu staf di sekolah-sekolah Muhammadiyah, beliau adalah guru-guru yang dididik di pondok pesantren. Kyai Amir menempati rumahnya untuk untuk mengajar ilmu agama yang nantinya berkembang menjadi Sekolah Pendidikan Guru Agama, Ma'had Islamy pada akhir tahun 1930 dan menarik minat terutama anak-anak santri dari pelosok Kotagede. ${ }^{6}$ Pandangan Mitsuo Nakamura dalam hal ini sependapat dengan yang disampaikan oleh Mahsun tentang kegiatan sosial Muhammadiyah di Jawa Tengah sebagai berikut, pada tahun 1932 Muhammadiyah telah mempunyai 165 sekolah umum di samping sekolah agama. Dalam perkembangan selanjutnya Muhammadiyah merupakan organisasi yang memiliki amal usaha paling banyak diantara organisasi Islam lainnya. ${ }^{7}$

Pembahasan ideologi Muhammadiyah, Mitsuo Nakamura melihat dari sisi tradisi dan transformasi budaya Jawa. Dalam pandangan Mitsuo Nakamura ideologi Muhammadiyah merupakan ideologi Islam yang murni, tetapi dalam menghadapi tradisi dan budaya jawa ideologi Muhammadiyah tidak pernah menolak budaya dan tradisi Jawa, tetapi berusaha untuk menyaring intisari Islam yang murni dari tradisi dan kebudayaan Jawa. Dalam gambaran Mitsuo Nakamura seperti sebuah cairan yang sangat murni, yang tidak bisa kehilangan bau khasnya. Akan tetapi intisari universal Islam lebih mendasar. ${ }^{8}$ Mitsuo Nakamura memprkuat pendapatnya tentang ideologi Muhammadiyah berkaitan dengan budaya dan tradisi Jawa berpendapat bahwa Islam

\footnotetext{
${ }^{6}$ Mitsuo Nakamura, The Crescent Arises Over The Banyan Tree: A Study of The Muhammadiyah Movement in Central of Javanese Town, (Yogyakarta: Gajah Mada University Press1983),104.

7 Mahsun, Muhammadiyah Gerakan Praksis Sosial Keagamaan Semangat Altruisme Dan Filantropisme. (Surabaya: CV.Jakad Media Nusantara,2017),87.

${ }^{8}$ Ibid, 171.
} 
reformis bukanlah antitesis budaya Jawa, melainkan bagian integral darinya, dan apa yang telah para reformis perjuangkan adalah, boleh dikatakan menyaring intisari murni Islam dari tradisi-tradisi budaya Jawa. Hasil akhir dari penyaringan ini tentu menyimpan citarasa Jawa, sama seperti cairan yang sangat murni apapun tak bisa kehilangan citarasa lokalnya. Tapi intisari Islam yang universal lebih mendasar, dan tentu harus dihargai sebagai yang pertama dan utama. ${ }^{9}$ Hal senada disampaikan oleh Mahsun yang berpendapat bahwa segala yang dilakukan oleh Muhammadiyah baik dalam bidang pendidikan, kemasyarakatan dan lainnya tidak bisa terlepas dari usaha untuk melaksanakan keyakinan Islam, sebab hanya dengan syariat Islam itulah kebahagiaan haqiqi dapat terwujud. ${ }^{10}$

\section{Analisis Penelitian}

a. Muhammadiyah Sebagai Gerakan Agama

Muhammadiyah dalam pandangan Mitsuo Nakamura adalah berdasarkan pada hasil penelitian lapangan yaitu di Kotagede selama sembilan belas bulan antara bulan Oktober tahun 1970 dan April tahun 1972 dan riset arsip selama dua bulan yang dilaksanakan di Belanda antara bulan Juni dan Agustus 1972. ${ }^{11}$ Penulis berusaha untuk menganalisis pernyataan Mitsuo Nakamura dengan cara mengalisis dengan data yang diperoleh dari buku dan sejarah tentang gerakan Muhammadiyah di Kotagede dari sumber yang lain. Dalam melihat Muhammadiyah di Kotagede Mitsuo Nakamura salah satunya adalah dengan melihat riwayat hidup pimpinan Muhammadiyah, karena menganggap dalam sejarah kehidupan tokoh itu peralihan kepada orientasi agama yang baru secara jelas terwujud.

Dalam hal ini saya sangat setuju karena sebagai pemimpin organisasi adalah menjadi contoh bagi umat. Sebagaimana dicontohkan diatas tentang keteguhan pendirian dari Kyai Haji Masyhudi yang tidak mengikuti adat kebiasaan masyarakat di Kotagede dengan alasan bahwa hal itu tidak sesuai dengan ajaran Islam, tapi dengan cara yang bijaksana. Pernyataan Mitsuo Nakamura tentang Muhammadiyah sebagai gerakan agama senada dengan sikap KH.Ahmad Dahlan dalam menyikapi budaya lokal seperti yang ditulis dalam buku Kuntowijoyo yang mengatakan bahwa orang mengingatnya (KH.Ahmad Dahlan) sebagai tokoh pemurnian Islam yang

\footnotetext{
${ }^{9}$ Mitsuo Nakamura, The Crecent Arises Over The Banyan Tree, A Study of The Muhammadiyah Movement in Central of Java (Yogyakarta: Gajah Mada University Press1983),141.

10 Mahsun, Muhammadiyah Gerakan Praksis Sosial Keagamaan Semangat Altruisme Dan Filantropisme. (Surabaya: CV.Jakad Media Nusantara,2017),283.

${ }^{11}$ Mitsuo Nakamura, The Crecent Arises Over The Banyan Tree, A Study of The Muhammadiyah Movement in Central of Java (Yogyakarta: Gajah Mada University Press1983),xi.
} 
konsekwen dengan gagasannya. Namun, rupanya Islam murni hanya berlaku bagi dirinya sendiri dan orang-orang yang sepaham, tetapi tidak untuk orang lain. ${ }^{12}$ Pendapat lain yang menguatkan tentang hasil penelitian Mitsuo dikemukakan oleh Yusron Asrofie dalam bukunya mengatakan bahwa KH.Ahmad Dahlan berusaha meluruskan ajaran agama, salah satunya adalah dengan memberantas bid'ah dan khurafat. ${ }^{13}$ Pendapat lain yang mendukung Muhammadiyah sebagai gerakan pemurnian agama adalah Mahsun, mengatakan bahwa tujuan utama Muhammadiyah adalah mengembalikan seluruh penyimpangan yang terjadi dalam proses dakwah. penyimpangan ini sering menyebabkan ajaran Islam bercampur-baur dengan kebiasaan di daerah tertentu dengan alasan adaptasi. ${ }^{14}$

b. Muhammadiyah Sebagai Gerakan Sosial

Dalam pandangan Mitsuo Nakamura Muhammadiyah adalah sebuah organisasi gerakan sosial, hal itu sudah dibuktikan dari hasil penelitian di lapangan yaitu di Kotagede. Pandangan Mitsuo Nakamura tentu harus dianalisa terlebih dahulu yaitu dengan mencari atau memadukan dengan data yang lain. Pembentukan PKU (Penolong Kesengsaraan Umat) merupakan bidang kegiatan sosial Muhammadiyah yang secara resmi dilembagakan, dimulai pada tahun 1918 sebagai organisasi independen dibentuk oleh beberapa anggota Muhammadiyah Yogyakarta untuk menangani kegiatan pertolongan darurat bagi korban letusan gunung Kelud. Pada tahun 1921 organisasi itu resmi menjadi bagian Muhammadiyah. ${ }^{15}$

c. Muhammadiyah Sebagai Gerakan ideologi

Pandangan Mitsuo Nakamura tentang Muhammadiyah sebagai gerakan ideologi hanya melihat dari apa saja yang sudah dilakukan oleh para anggota Muhammdiyah di Kotagede dalam rangka mewujudkan suatu ideologi Muhammadiyah, dalam hal ini yang dimaksud dengan ideologi Muhammadiyah adalah berhubungan dengan adat kebiasaan masyarakat di Kotagede. Muhammadiyah sebagai gerakan ideologi dalam menyikapi adat dan tradisi masyarakat Kotagede tidak pernah menentang dengan adat dan tradisi masayarakat Kotagede, Muhammadiyah hanya menyaring intisari dari nilai

\footnotetext{
${ }^{12}$ Kuntowijoyo, Menghias Iman dalam Abdul Munir Mulkan, Marhaenis Muhammadiyah: Ajaran dan Pemikiran KH.Ahmad Dahlan (Yogyakarta: Galang Pustaka, 2013), 18.

13 Yusron Asrofie, Kyai Haji Ahmad Dahlan Pemikiran Dan Kepemimpinannya. (Yogyakarta: Yogyakarta Offset,1983),43.

14 Mahsun, Muhammadiyah Sebagai Gerakan Tajrid Dan Tajdid, (Surabaya: Perwira Media Nusantara,2014),1.

${ }^{15}$ Mitsuo Nakamura, The Crecent Arises Over The Banyan Tree, A Study of The Muhammadiyah Movement in Central of Java (Yogyakarta: Gajah Mada University Press1983),111.
} 
ajaran Islam dalam adat Jawa, hasil penyaringan itu tetap berbau Jawa, persis seperti cairan apapun yang sangat murni tidak bisa kehilangan bau khasnya. Akan tetapi nilai universal Islam lebih mendasar dan harus dinilai sebagai yang pertama dan terpenting.

\section{Kesimpulan dan Rekomendasi}

1. Kesimpulan

Muhammadiyah dalam pandangan Mitsuo Nakamura sebagai gerakan agama dalam buku "The Crescent Arises over The Banyan Tree A Study of The Muhammadiyah Movement in Central of Javanese Town" menegaskan bahwa Muhammadiyah sebagai gerakan agama adalah berusaha untuk mewujudkan pemurnian ajaran agama Islam dari hal-hal yang bukan berasal dari agama Islam. Tetapi hal itu berlaku hanya bagi anggota Muhammadiyah. pendapat Nakamura sepaham dengan pernyataan dari Kuntowijoyo dalam bukunya mengatakan bahwa Islam murni hanya berlaku bagi dirinya sendiri (KH.Ahmad Dahlan) dan orang-orang yang sepaham, tetapi tidak untuk orang lain. ${ }^{16}$ reformasi telah muncul dari kalangan Islam Jawa tradisional sebagai penjelmaan dari dalam dan bukan sebagai ideologi impor, yang telah dan akan membawa perubahan-perubahan besar di dalam aspek sosial, kultural, ekonomi dan politik dari pada kehidupan masyarakat Jawa pada khususnya, dan masyarakat Indonesia pada umumnya.

Muhammadiyah dalam pandangan Mitsuo Nakamura sebagai gerakan sosial dalam buku "The Crescent Arises over The Banyan Tree A Study of The Muhammadiyah Movement in Central of Javanese Town”. Muhammadiyah memandang masalah sosial sebagai bagian dari agama, hal itu dapat dilihat dari semangat Muhammadiyah dalam amal usaha bidang sosial antara lain dengan mendirikan PKU (Penolong Kesengsaraan Umat), klinik rumah sakit dan juga amal usaha mendirikan sekolah Muhammadiyah untuk mengajarkan ilmu pengetahuan dan sebagai lahan da'wah Islam Muhammadiyah.

Muhammadiyah sebagai ideologi dalam pandangan Mitsuo Nakamura merupakan gerakan ideologi Islam yang murni, tetapi dalam menghadapi tradisi dan budaya jawa ideologi Muhammadiyah tidak pernah menolak budaya dan tradisi Jawa, tetapi berusaha untuk menyaring intisari Islam yang murni dari tradisi dan kebudayaan Jawa. Dalam gambaran Mitsuo Nakamura seperti sebuah cairan yang

\footnotetext{
${ }^{16}$ Kuntowijoyo, "Menghias Islam” dalam Abdul Munir Mulkan, Marhaenis Muhammadiyah: Ajaran dan Pemikiran KH.Ahmad Dahlan, (Yogyakarta: Galang Pustaka, 2013), 18.
} 
sangat murni, yang tidak bisa kehilangan bau khasnya. Akan tetapi intisari universal Islam lebih mendasar.

2. Rekomendasi

Muhammadiyah dalam Pandangan Mitsuo Nakamura seperti yang ditulis dalam buku "The Crescent Arises over The Banyan Tree" A Study of The Muhammadiyah Movement in Central of Javanese Town" hanya disekitar Kotagede dan sedikit di paparkan oleh Mitsuo Nakamura, sehingga masih memberikan ruang penelitian pada peneliti lain tentang Muhammadiyah secara lebih luas baik wilayah, ideologi, sosial, agama, dan pendidikan. Pada buku tersebut ini tidak dijelaskan sebab KH. Ahmad Dahlan mendirikan Muhammadiyah. Hal ini dapat pula menjadi bahan pertimbangan untuk dilakukan penelitian lebih lanjut.

\section{Referensi}

Adijani, Al-Alabij. 2002. Perwakafan Tanah di Indonesia, cet. ke-4. Jakarta: Rajawali Pers.

Arikunto, Suharsimi. 1995. Manajemen Penelitian, cet. Ke-3. Jakarta: PT. Rieneka Cipta.

Arikunto, Suharsimi. 2010. Prosedur Penelitian Suatu Pendekatan Praktik. Jakarta: Rineka Cipta.

Asrofie, Yusron. 1983. Kyai Haji Ahmad Dahlan Pemikiran Dan Kepemimpinannya. Yogyakarta: Yogyakarta Offset.

Bakker, Anton dan Achmad Charris Zubair. 1990. Metode Penelitian Filsafat. Yogyakarta: Konisius.

Bunging, Burhan. 2015. Penelitian Kualitatf, Jakarta: Prenada Media Group.

Kasiran, Moh. 2010, Metodologi Penelitian, Refleksi Pengembangan Pemahaman dan Penguasaan Metodologi Penelirian, Cet.Ke-2 Malang: UIN Maliki.

Mahsun. 2017, Muhammadiyah Gerakan Praksis Sosial Keagamaan Semangat Altruisme Dan Filantropisme, Surabaya: CV.Jakad Media Nusantara.

Mahsun. 2014, Muhammadiyah Sebagai Gerakan Tajrid dan Tajdid, Surabaya:CV. Perwira Media Nusantara.

Mahmud. 2011, metode penelitian pendidikan, Bandung: pustaka setia.

Mansur, dkk. 2005, Rekonstruksi Sejarah Pendidikan Islam di Indonesia, Jakarta: Depag. 
Moleong, Lexy J. 2004, Metodologi Penelitian Kualitatif cet.Ke-20, Bandung: PT. Remaja rosdakarya.

Muhammadiyah. 2010, Yogyakarta: Surya Sarana Grafika.

Nakamura, Mitsuo. 1993, Bulan Sabit Muncul Dari Balik Pohon Beringin, Yogyakarta: Gajah Mada University Press.

Nakamura, Mitsuo. 1983, Bulan Sabit Muncul Dari Balik Pohon Beringin. Yogyakarta: Gajah Mada University Press.

Nugraha, Adi. 2010, KH.Ahmad Dahlan, Biografi Singkat 1869-1923, Yogjakarta: Garasi House of Book.

PP Muhammadiyah, AD dan ART Muhammadiyah, Hasil Muktamar Muhammadiyah ke-45 (Malang: 2005), Bab I pasal 2, dan Bab II pasal 4.

PP.Muhammadiyah, AD Muhammadiyah (Yogyakarta: Toko Buku Suara Muhammadiyah,2005)

Pimpinan Pusat Muhammadiyah, Anggaran Dasar dan Anggaran Rumah Tangga

Pimpinan Pusat Muhammadiyah. 2006: Lampiran Surat Keputusan Pimpinan Pusat Muhammadiyah Nomor: 120/KEP/I.0/B/2006 Tentang: Qa idah Unsur Pembantu Pimpinan Persyarikatan, Yogyakarta.

Pimpinan Pusat Muhammadiyah. 2010, Berita Resmi Muhammadiyah No. 01/20102015/Syawwal 1431 H/September 2010 M tentang Tanfidz Keputusan Muktamar Satu Abad Muhammadiyah Muktamar Muhammadiyah Ke 46. Yogyakarta.

Rahman Saleh, Abdul. 2005, Pendidikan Agama dan Pengembangn untuk Bangsa, Jakarta: PT. Raja Grafindo Persada.

Sugiyono. 2012, Metode Penelitian Kualitatif Kuantitatif dan R\&D cet.Ke-17, Alfabeta, Bandung.

Sutrisno, Hadi. 1989, Metode Research, , Yogyakarta: Andi Offset.

Surahmad, Winarno.1988, Dasar Dan Tehnik Research Pengantar Metodologi Ilmiah, Bandung:Tarsito.

Sutarmo. 2005, Muhammadiyah Gerakan Sosial Keagamaan Modernis, Yogyakarta:Suara Muhammadiyah.

Wibisono, Fatah. Masyarakat Islam Yang Sebenar-benarnya:Kajian Teks, PP Muhammadiyah Majlis Tarjih dan Tajdid. 
https://en.wikipedia.org/wiki/Mitsuo Nakamura (cultural anthropologist)

http://www.muhammadiyah.or.id/id/content-204-det-susunan-pimpinan-pusatmuhammadiyah.html diakses 09/08/2018 pukul.18.30 bbwi 